\title{
Identification of Serk Gene from Bract Derived Embryogenic and Non - Embryogenic Calli of Four Diploid Banana Cultivars from South India
}

\author{
Smitha P D (Corresponding author) \\ Assistant professor, Department of Botany, Sree Narayana College, \\ Kollam. E-mail: smithadivakaran2009@gmail.com \\ Binoy K R \\ Assistant Professor, Department of Botany, Govt. College, Kariavattom
}

Ashalatha S Nair

Professor, Department of Botany, University of Kerala,

Kariavattom, Thiruvananthapuram 695581, India.

Received: September 25, 2017 Accepted: October 11, 2017 Published: November 30, 2017

doi:10.5296/jas.v5i4.12213 URL: https://doi.org/10.5296/jas.v5i4.12213

\begin{abstract}
Somatic embryogenesis receptor kinase (SERK) gene is known to be a marker of somatic embryogenesis in several plant species. The present study reported the presence of SERK gene from bract derived embryogenic calli bearing somatic embryos. The analysis of the expression pattern of the SERK gene during embryogenic cell formation and somatic embryogenesis revealed that SERK expression continued during pro embryogenic mass formation. In the present study the amplified product of cDNA from the somatic embryos has molecular size $1459 \mathrm{bp}$. The non- embryogenic callus also showed the presence of faint bands. In all the samples the amplified product from $\beta$ - actin primer showed bands of $650 \mathrm{bp}$ with similar intensity in both the embryogenic and non- embryogenic samples.
\end{abstract}

Keywords: SERK gene, Diploid, Embryogenic, Non- embryogenic calli 


\section{Introduction}

Somatic embryogenesis is the process where by differentiated somatic cells acquire competence and proliferation as embryogenic cells. Initiation of embryogenic pathway is restricted to certain responsive cells that have the potential to activate genes involved in generating embryogenic cells (Quiroz - Figueroa et al. 2002). Once these genes are activated, an embryogenic gene expression program replaces the established gene expression pattern in the explant tissue (Quiroz - Figueroa et al. 2006). During somatic embryogenesis, somatic cells are induced to form totipotent embryogenic cells capable of regenerating into complete plants. Such developmental switching involves a series of events associated with the molecular recognition of internal signals and external stimuli (Chugh \& Khurana, 2002). The perception and response to these events set off various signal cascades, and the downstream pathways followed during the transition of single cells to somatic embryo eventually results in specific gene expression and somatic embryogenesis (Zimmerman, 1993; Chugh \& Khurana, 2002; Feher et al. 2003). Analysis of gene expression during somatic embryogenesis provide information for better understanding of the process. Additionally somatic embryo models are useful for studying cell differentiation process in plants and for understanding the functional aspects of genes already implicated in somatic embryogenesis (Quiroz - Figueroa et al. 2006). It is important to identify a reliable molecular marker system that can be used for improvement of embryogenic competence cultures of banana. Moreover, isolation and cloning of disease resistance $(\mathrm{R})$ genes are needed for introducing resistance to fungal pathogens in banana (Pei et al. 2006). Somatic embryogenesis receptor-like kinases (SERKs) are reported to play important roles in the process of somatic embryogenesis, and they belong to the super family of leucine - rich repeat receptor like kinases (LRR- RLK) (Schmidt et al. 1997). A number of full - length SERK genes have been isolated, such as DcSERK from carrot (Schmidt et al. 1997), AtSERK1 from Arabidopsis (Hecht et al. 2001), ZmSERK1 from maize (Baudino et al. 2001), and OsB1SERK1 from rice (Song et al. 2008).

\section{Materials and Methods}

Male flower bunches were obtained from adult field - grown banana after maturation of fruit bunch. The bracts with associated hands of male flowers were removed in a step-wise manner until they become too small to be removed by hand. The remaining portion having an approximate size of 4-5 cm length was immersed in 1\% (v/v) Labolene ${ }^{\circledR}$ for 6 min and kept under running tap water for $30 \mathrm{~min}$. The explants were surface sterilized in $0.1 \%(\mathrm{w} / \mathrm{v})$ mercuric chloride for $4 \mathrm{~min}$ followed by three rinses in autoclaved double-distilled water, 5 min for each rinse. Two or three outer protective bracts and corresponding groups of male flowers were sequentially discarded. $\sim 1 \mathrm{~cm}$ square pieces from the basal region of inner bracts were excised, the male flowers with a single cut and the bract was inoculated on MS medium supplemented with TDZ $(0.045-9.00 \mu \mathrm{M}), 2-4, \mathrm{D}(0.45-4.5 \mu \mathrm{M}), 0.30 \mathrm{gl}^{-1}$ sucrose, $0.7 \mathrm{gl}^{-1}$ agar. The ${ }_{\mathrm{p}} \mathrm{H}$ of the media was adjusted to 5.8 before autoclaving at $120^{\circ} \mathrm{C}$ for $18 \mathrm{~min}$. The cultures were maintained at a temperature of $25 \pm 2^{\circ} \mathrm{C}$ with a photoperiod of $16 \mathrm{~h} /$ day under $50 \mu \mathrm{mol} \mathrm{m} \mathrm{m}^{-2} \mathrm{~s}^{-1}$ light intensity provided by fluorescent lamps. RNA was isolated from embryogenic calli regenerated on MS medium with TDZ $(0.45 \mu \mathrm{M})$, non - embryogenic calli regenerated on MS medium with 2, 4-D $(0.45 \mu \mathrm{M})$ and tissue isolated from bract meristem 
(0.5 gm each) as control from the four diploid Musa acuminata cultivars cv. Matti, cv. Sannachenkadali, cv. Chingan and cv. Njalipoovan. The samples were frozen with liquid nitrogen and powdered using a mortar and pestle. Small portions of powdered sample were added to a vial containing $3 \mathrm{ml}$ of extraction buffer (150 Mm Tris base hydroxymethyl hydrochloride), $2 \%$ (w/v) SDS, $100 \mathrm{Mm}$ EDTA adjusted to $\mathrm{pH} 7.5$ with saturated boric acid and $30 \mu \mathrm{l}$ of $\beta$-mercaptoethanol (1\%,v/v). This suspension was quickly mixed using a cut tip to avoid RNA damage and transferred to eppendorff tubes ( $750 \mu l$ per tube), precipitated with $66 \mu \mathrm{l} 5 \mathrm{M}$ potassium acetate and $150 \mu \mathrm{l}$ absolute ethanol, vortexed for 1 min, added 850 $\mu \mathrm{l}$ chloroform - isoamyl alcohol $(49: 1, \mathrm{v} / \mathrm{v})$, centrifuged at $16,000 \mathrm{~g}$ for $20 \mathrm{~min}$ and the supernatant collected into an eppendorff tube. The suspension was again vortexed for 10 seconds and centrifuged at $16,000 \mathrm{~g}$ for $20 \mathrm{~min}$ at room temperature. The supernatant were recovered and transferred to new tubes and added $850 \mu 1$ phenol-chloroform-isoamyl alcohol $(25: 24: 1, \mathrm{v} / \mathrm{v} / \mathrm{v})$ per tube, vortexed for $10 \mathrm{sec}$ and centrifuged at 16,000g for $15 \mathrm{~min}$ at room temperature. The supernatant was recovered, transferred to new tubes, along with $850 \mu \mathrm{l}$ chloroform-isoamyl alcohol. The tubes were vortexed for 10 seconds and centrifuged at $16,000 \mathrm{~g}$ for $15 \mathrm{~min}$ at $4^{\circ} \mathrm{C}$. The supernatant was recovered, $12 \mathrm{M} \mathrm{LiCl}_{2}$ was added to a final concentration of $3 \mathrm{M}$, and the tubes with RNA samples were gently mixed by inversion and left to stand overnight at $-20^{\circ} \mathrm{C}$. The samples were centrifuged at $16,000 \mathrm{~g}$ for $20 \mathrm{~min}$ at $4^{\circ} \mathrm{C}$, the pellets were washed twice with $70 \%$ ethanol $(500 \mu \mathrm{l}$ each) and centrifuged again at $16,000 \mathrm{~g}$ for $10 \mathrm{~min}$ at $4^{\circ} \mathrm{C}$. The pellets were dried at room temperature and resuspended in 10 $\mu 1$ DEPC (Diethyl pyrocarbonate) treated sterile distilled water. The suspension was pooled in a new tube and stored at $-80^{\circ} \mathrm{C}$ until use. Quantification of RNA samples were done by using Bio-photometer (Eppendorf's, Germany). RNA sample $(2 \mu \mathrm{l})$ was dissolved in $48 \mu \mathrm{l}$ DEPC treated water and absorbance at 260 and $280 \mathrm{~nm}$ was taken. The ratio between 260/ 280 was calculated to assess the purity of samples.

First strand cDNA synthesis was performed from the total RNA isolated from selected tissue samples. Reaction mixture was prepared according to the manufacturer's protocol (Fermentas, Lifescience). Each reaction mixture containing DNAse treated RNA sample (20 ng), oligo dT primer $(0.5 \mu \mathrm{g})$ and the volume adjusted to final $(11.5 \mu \mathrm{l})$ with DEPC treated water. A quick spin was given for the mixture for $5 \mathrm{sec}$ and incubated at $65^{\circ} \mathrm{C}$ for $5 \mathrm{~min}$, chilled on ice and given another short spin to collect droplets sticking on the tube. The mixture was kept on ice and $4 \mu \mathrm{l} 5 \mathrm{X}$ reaction buffer, $0.5 \mu \mathrm{l}$ of $20 \mathrm{u}$ of Ribo Lock TM ribonuclease inhibitor, $2 \mu \mathrm{l}$ of $1 \mathrm{mM}$ dNTP mixture, $40 \mathrm{u}$ of M - MuLV reverse transcriptase $(2 \mu \mathrm{l})$ were added and the final volume adjusted to $20 \mu \mathrm{l}$. The reaction mixture mixed gently by a short spin. This reaction was incubated at $37^{\circ} \mathrm{C}$ for $60 \mathrm{~min}$ and was terminated by heating at $70^{\circ} \mathrm{C}$ for $10 \mathrm{~min}$. This mixture was stored at $-20^{\circ} \mathrm{C}$.

PCR amplification of specific gene (SERK) was carried out from the synthesized cDNA. The PCR reaction was carried out in a DNA Thermal cycler (Master cycler gradient, Eppendorf). Amplification condition were $200 \mu \mathrm{M}$ dNTP $(0.4 \mu \mathrm{l}), 1.25 \mathrm{u}$ Taq polymerase $(1 \mu \mathrm{l}), 1 \mathrm{X}$ Taq polymerase buffer with $\left(\mathrm{NH}_{4}\right)_{2} \mathrm{SO}_{4}(2 \mu \mathrm{l}), 25 \mathrm{mM} \mathrm{MgCl} 2(0.8 \mu \mathrm{l})$ and $5 \mathrm{Mm}$ primer (SERK R and F) $(1 \mu \mathrm{l}$ each) with $20 \mu \mathrm{g}$ cDNA. The PCR amplification was done by using specific primers, SERK F (5'-ATG TCA CTG ACT AAT ATG ACA ACA CTT CAA G-3') and SERK 


\section{Macrothink}

Journal of Agricultural Studies

ISSN 2166-0379

2017, Vol. 5, No. 4

R (5'- TGT ACA TGG GTC TCC TTG TAC TCC AT-3') with the following PCR conditions: $94^{\circ} \mathrm{C}(2 \mathrm{~min})$; four cycles at $94^{\circ} \mathrm{C}(30 \mathrm{sec}) ; 45^{\circ} \mathrm{C}(4 \mathrm{~min}) ; 72^{\circ} \mathrm{C}(1.5 \mathrm{~min}) ; 28$ cycles at $94^{\circ} \mathrm{C}$ (30 sec); $63{ }^{\circ} \mathrm{C}(45 \mathrm{sec}) ; 72^{\circ} \mathrm{C}(1.5 \mathrm{~min})$; and $72^{\circ} \mathrm{C}(8 \mathrm{~min})$.

\section{Results}

To understand and compare the gene expression (SERK) during somatic embryogenesis embryogenic calli induced from bract explant inoculated on MS medium fortified with TDZ $(0.45 \mu \mathrm{M})$ and non- embryogenic calli induced in the presence of 2,4-D $(0.45 \mu \mathrm{M})$ and control tissue ( bract meristem) were selected. Isolated RNA samples from embryogenic and non-embryogenic calli and bract meristem showed two fragment of $28 \mathrm{~S}$ and 18S rRNA (Fig. 1). The amplified product of cDNA from all the samples has molecular size 1459 bp (Fig. 2). The amplified product from embryogenic callus showed maximum relative intensity of the segment with $31.35 \mathrm{ng}$ and $30.17 \mathrm{ng}$ in cvs. Matti and Sannachenkadali respectively. Minimum relative intensity (25.89 ng) was observed in cv. Njalipoovan. Non - embryogenic calli showed relative intensity between 26.90 and $29.41 \mathrm{ng}$. The control sample (bract meristem tissue) showed relative intensity $24.76 \mathrm{ng}$. All the embryogenic samples exhibited higher intensity bands compared to non- embryogenic and control samples. Amplification of all the samples in presence of $\beta$ - actin primer showed amplified product of $650 \mathrm{bp}$ with similar intensity (Fig. 3). 


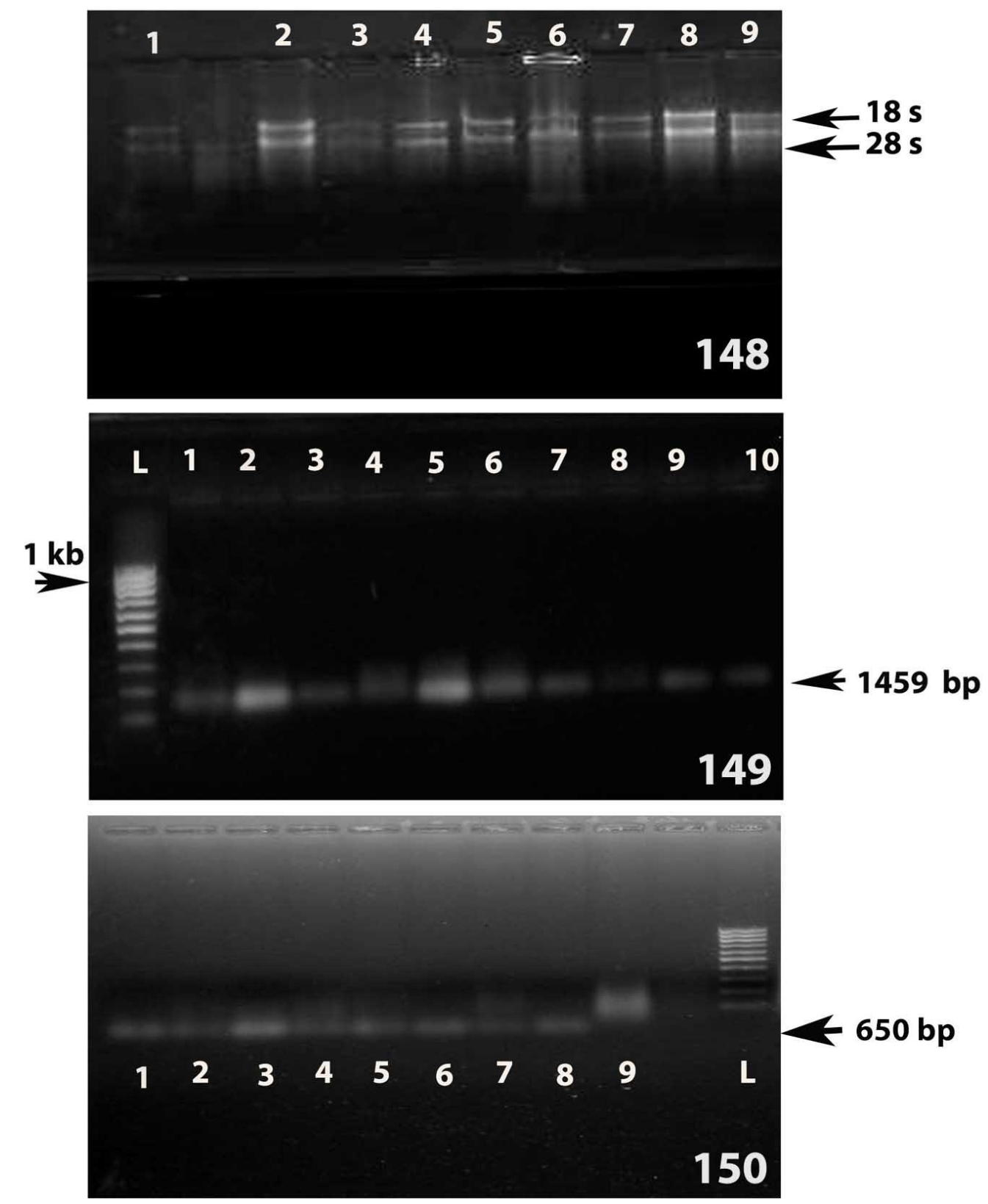

Fig 148. Isolated RNA samples with two bands of $28 \mathrm{~S}$ and $18 \mathrm{~S}$ rRNA, (Lane 1Control, Lane 2-5 non- embryogenic callus from cv. Matti, cv. Sannachenkadali, cv. Chingan \& cv. Njalipoovan, Lane 6-9 embryogenic callus from cv. Matti, cv.Sannachenkadali, cv. Chingan \& cv. Njalipoovan, Fig 149. Amplified product of cDNA has molecular size 1459 bp, (L- ladder, Lane 1- control, Lane 2- Ec of cv. Matti, Lane 3 \& 4- Nec of cv. Matti, Lane 5- Ec of cv. Sannachenkadali, Lane 6- Nec of cv. Sannachenkadali, Lane7- Ec of cv. Chingan, Lane 8-Nec of cv. Chingan, Lane 9- Ec of cv. Njalipoovan, Lane 10- Nec of cv. Njalipoovan), Fig 150. Amplified product of $\beta$-actin primer showed $650 \mathrm{bp}$ with similar intensity (Lane 1- $4 \mathrm{Nec}$ of cv. Matti, cv. Sannachenkadali, cv. Chingan \& cv. Njalipoovan, Lane 5 -8 Ec of cv. Matti, cv. Sannachenkadali, cv. Chingan \& cv. Njalipoovan, Lane 9- Control) (EcEmbryogenic callus, Nec- Non-embryogenic callus) 


\section{Discussion}

The most challenging aim of current somatic embryo research was to identify genes involved in the induction of embryogenesis competence and subsequent embryo development. Great progress in molecular analysis of plant embryogenesis was noticed in the last few years with the advent of modern molecular tools allowing fast and comprehensive gene expression analysis. Interaction between external stimuli and genes determining embryogenic competence and thus switching on development of embryos in vegetative tissue, was investigated at the molecular level (Feher et al. 2003). Understanding gene function and gene expression profile was achieved with several approaches such as analysis of the genome, the transcriptome, the metabolome and the analysis of proteome (Carpentier et al. 2007). The study of gene expression and its regulation "transcriptome" was achieved at the level of transcripts (RNA). In Musa 36,542 protein-coding gene models were reported. Among these are 89 defence-related genes encoding nucleotide-binding site leucine-rich repeat proteins were also reported (D'Hont et al. 2012). The Musa balbisiana genome has been associated with improved vigour and tolerance to biotic and abiotic stresses. The ' $\mathrm{B}$ ' genome was $79 \%$ of the size of the 'A' genome and contains 36,638 predicted functional gene sequences which was nearly identical to the 36,542 of the 'A' genome (Davey et al. 2013).

The analysis of the expression pattern of the SERK gene during embryogenic cell formation and during somatic embryogenesis revealed that SERK expression continued during pro embryogenic mass formation. In the present study the amplified product of cDNA has molecular size of $1459 \mathrm{bp}$. In all the samples the amplified product from $\beta$ - actin primer showed amplified product of $650 \mathrm{bp}$ with similar intensity. In Maize also a gene encoding two novel members of the leucine-rich repeat receptor-like kinase (LRR-RLK) super family was isolated (ZmSERK1 and ZmSERK2). The predicted SERK protein sequence resembled a leucine rich receptor kinase protein (Chang et al. 1992). In Musa acuminata cv. Mas (AA), a SERK gene (MaSERK) was characterized and reported that open reading frame of MaSERK1 was 1,887 bp in length and encoded 628 amino acids with calculated molecular mass of $69.53 \mathrm{kDa}$ (Huang et al. 2010). Ma SERK1 was expressed weakly in male flower clusters, but not in male flower derived non - embryogenic calli, but it was highly expressed in male flower derived embryogenic calli and embryogenic cell suspension. In the present study also SERK gene fragment showed maximum relative intensity in embryogenic tissues. In Arabidopsis AtSERK1 expression was not restricted to embryogenic cells, but it was characteristic of those cells capable of responding to hormonal signals and competent to form somatic embryos or embryogenic cell cultures (Hecht et al. 2001).

Somatic embryogenesis receptor - like kinase (SERK) genes encode leucine - rich repeat receptor - like kinases (LRR - RLKs), and the first SERK gene identified was reported in carrot (Daucus carota) suspension cultures where it was specifically expressed in cells that developed into somatic embryos (Schmidt et al. 1997). SERK constitute a special subgroup of receptor protein kinases associated with the process of somatic embryogenesis (Becraft, 1998). SERK genes were linked to somatic embryogenesis in a number of species including Dactylis glomerata (Somleva et al. 2000), Arabidopsis thaliana (Hecht et al. 2001), Medicago truncatula (Nolan et al. 2003) and Helianthus annuus (Thomas et al. 2004). SERK 
genes were also described in relation to apomixis in Hieracium (Tucker et al. 2003) and Poa pratensis (Albertini et al. 2005) as well as zygotic embryogenesis in carrot, Arabidopsis, and wheat (Schmidt et al. 1997; Hecht et al. 2001; Singla et al. 2008). The best defined SERK gene in relation to somatic embryogenesis was the Arabidopsis SERK1 (AtSERK1) and over expression of this SERK was shown to enhance embryogenic competence in Arabidopsis cultures (Hecht et al. 2001). SERK genes existed as gene families in many species with five SERK genes in Arabidopsis. The role of MtSERK1 in cultured tissue of M. truncatula was previously studied (Nolan et al. 2003), indicated that MtSERK1 expression in culture was not only related to somatic embryogenesis, but also to organogenesis and, possibly, other forms of cellular reprogramming. There was an increased understanding of the SERK family in recent years (Song et al. 2008).

\section{References}

Albertini, E., Marconi, G., Reale, L., Barcaccia, G., Porceddu, A., Ferranti, F., \& Falcinelli, M. (2005). SERK and APOSTART. Candidate genes for apomixis in Poa pratensis. Plant Physiol., 138: 2185 - 2199. https://doi.org/10.1104/pp.105.062059

Baudino, S., Hansen, S., Brettschneider, R., Hecht, V., Dresselhaus, T., Lo, H., Dumas, C., \& Rogowsky, P. (2001). Molecular characterization of two novel maize LRR receptor - like kinases, which belong to the SERK gene family. Planta., 213: 1-10.

https://doi.org/10.1007/s004250000471

Becraft PW (1998). Receptor kinases in plant development. Trends. Plant Sci., 3: 384 - 388. https://doi.org/10.1016/S1360-1385(98)01301-6

Carpentier, S.C., Witters, E., Laukens, K., Van Onckelen, H., Swennen, R., \& Panis, B. (2007). Banana (Musa spp.) as a model to study the meristem proteome: Acclimation to osmotic stress. Proteomics., 7: 92 - 105. https://doi.org/10.1002/pmic.200600533

Chang, C., Schaller, G.E., Patterson, S.E., Kwok, S.F., Meyerowitz, E.M., \& Bleecker, A.B. (1992). The TMK1 gene from Arabidopsis codes for aprotein with structural and biochemical characteristics of a receptor protein kinase. Cell., 4: 1263 -1271.

Chugh, A., \& Khurana, P. (2002). Gene expression during somatic embryogenesis - recent advances. Curr Sci., 83: $715-730$.

D’Hont, A., Denoeud, F., Aury, M., J., Baurens, F. C., Carreel1, F., Garsmeur, O., ..., \& Wincker, P. (2012). The banana (Musa acuminata) genome and the evolution of monocotyledonous plants. Nature., 488: 213 - 219. https://doi.org/10.1038/nature11241

Davey, W.M., Gudimella, R., Harikrishna, A.J, Sin, W.L., Khalid, N., \& Keulemans, J.(2013). A draft Musa balbisiana genome sequence for molecular genetics in polyploid, inter - and intra - specific Musa hybrids . http://www.biomedcentral.com/1471-2164/14/683.

Feher, A., Pasternak, T.P., \& Dudits, D. (2003). Transition of somatic plant cells to an embryogenic state. Plant Cell Tiss Org Cult 74: 201 - 228.

https://doi.org/10.1023/A:1024033216561 
Hecht, V., Vielle - Calzada, J.P., Hartog, M.V., Schmidt, E.D.L., Boutlier, K., Grossniklaus, U., \& de Vries, S.C. (2001). The Arabidopsis somatic embryogenesis receptor kinase 1 gene is expressed in developing ovules and embryos and enhances embryogenic competence in culture. Plant Physiol. 127: 803 - 816. https://doi.org/10.1104/pp.010324

Huang, X., Lu, X.Y., Zhao, J.T., Chen, J.K., Dai, X.M., Xiao, W., Chen, Y.P., Chen, Y.F., \& Huang, X.L. (2010). MaSERK1 gene expression associated with somatic embryogenic competence and disease resistance response in banana (Musa spp.). Plant Mol Biol Rep. 28: 309 - 316. https://doi.org/10.1007/s11105-009-0150-z

Nolan, K.E., Irwanto, R.R., \& Rose, R.J. (2003). Auxin up - regulates MtSERK1 expression in both Medicago truncatula root - forming and embryogenic cultures. Plant Physiol., 133: 218 - 230. https://doi.org/10.1104/pp.103.020917

Pei, X., Li, S., Jiang, Y., Zhang, Y., Wang, Z., \& Jia, S. (2006). Isolation, characterization and phylogenetic analysis of the resistance gene analogues (RGAs) in banana (Musa spp.). Plant Sci., 172: 1166 - 1174. https://doi.org/10.1016/j.plantsci.2007.02.019

Quiroz - Figueroa, F.R., Fuentes - Cerda, C.F.J., Rojas - Herrera, R., Loyola - Vargas, V.M. (2002). Histological studies on the developmental stages and differentiation of two different somatic embryogenesis systems of Coffea Arabica. Plant Cell Rep. 20: 1141 - 1149.

https://doi.org/10.1007/s00299-002-0464-x

Quiroz - Figueroa, F.R., Rojas - Herrera, R., Galaz - Avalos, R.M., \& Loyola - Vargas, V.M. (2006). Embryo production through somatic embryogenesis can be used to study cell differentiation in plants. Plant Cell Tiss. Org. Cult. 86: 285 - 301.

https://doi.org/10.1007/s11240-006-9139-6

Schmidt, E.D.L., Guzzo, F., Toonen, M.A.J., de Vries, S.C. (1997). A leucine - rich repeat containing receptor - like kinase marks somatic plant cells competent to form embryos. Development., 124: 2049 - 2062.

Singla, B., Khurana, J.P., \& Khurana, P. (2008). Characterization of three somatic embryogenesis receptor kinase genes from wheat, Triticum aestivum. Plant Cell Rep. 27: 833 - 843. https://doi.org/10.1007/s00299-008-0505-1

Somleva, M.N., Schmidt, E.D.L., \& DE Vries, S.C. (2000). Embryogenic cells in Dactylis glomerata L. (Poaceae) explants identified by cell tracking and by SERK expression. Plant Cell Rep., 19: 718 - 726. https://doi.org/10.1007/s002999900169

Song, D., Li, G., Song, F., \& Zheng, Z. (2008). Molecular characterization and expression analysis of $O S B I S E R K 1$, a gene encoding a leucine - rich repeat receptor - like kinase, during disease resistance response in rice. Mol. Biol. Rep. 35: 275 - 283.

https://doi.org/10.1007/s11033-007-9080-8

Stasolla, C., Belmonte, M., Van Zyl, L., Craig, D.L., Liu, W., Yeung, E.C., \& Sederoff, R.R. (2004). The effect of reduced glutathione on morphology and gene expression of white spruce (Picea glauca) somatic embryos. J. Exp. Bot., 55: 695 - 709. 
https://doi.org/10.1093/jxb/erh074

Thomas, T. L. (1993). Gene expression during plant embryogenesis and germination: an overview. Plant Cell., 5: 1401 - 1410. https://doi.org/10.1105/tpc.5.10.1401

Zimmerman, J. L. (1993). Somatic embryogenesis: a model for early development in higher plants. Plant Cell., 5: 1411 - 1423. https://doi.org/10.1105/tpc.5.10.1411

\section{Copyright Disclaimer}

Copyright for this article is retained by the author(s), with first publication rights granted to the journal.

This is an open-access article distributed under the terms and conditions of the Creative Commons Attribution license (http://creativecommons.org/licenses/by/4.0/). 